\title{
Temperature Based Spatiotemporal Growth Monitoring of Rice Plant from Germination-Ripening Stage Using Remote Sensing and GIS Techniques
}

\author{
S. M. H. Raza ${ }^{*}$, S. A. Mahmood'1, H. Batool' ${ }^{2}$, T. J. Shad ${ }^{1}$, S. Alvi' ${ }^{1}$, F. Waseems ${ }^{1}$, M. Atif Butt ${ }^{1}$, \\ S. Shehzad Hassan ${ }^{1}$, Ali Imam Mirza ${ }^{1}$
}

${ }^{1}$ Remote Sensing and GIS Group, Department of Space Science, University of the Punjab, Quaid-e-Azam Campus, Lahore, Pakistan

${ }^{2}$ Department of Geography, University of the Punjab, Quaid e Azam Campus, Lahore, Pakistan

Email: *smhn72@gmail.com

How to cite this paper: Raza, S.M.H., Mahmood, S.A., Batool, H., Shad, T.J., Alvi, S., Waseems, F., Butt, M.A., Hassan, S.S. and Mirza, A.I. (2018) Temperature Based Spatiotemporal Growth Monitoring of Rice Plant from Germination-Ripening Stage Using Remote Sensing and GIS Techniques. Advances in Remote Sensing, 7, $1-14$.

https://doi.org/10.4236/ars.2018.71001

Received: October 26, 2017

Accepted: February 24, 2018

Published: February 28, 2018

Copyright (c) 2018 by authors and Scientific Research Publishing Inc. This work is licensed under the Creative Commons Attribution International License (CC BY 4.0).

http://creativecommons.org/licenses/by/4.0/

(c) (i) Open Access

\begin{abstract}
Rice (Oryza sativa) is the second staple food largely grown and widely consumed in Pakistan. About 10\% of the total crop area of Pakistan is cultivated by rice that takes a part in value addition of almost $1.3 \%-1.6 \%$ in the total Gross Domestic Product (GDP). Due to global warming, temperature has a profound impact on rice crop phenology. Low temperature is the main factor of delay in rice plant growth and very high temperature results in stressed and short heighted plant so the crop sown in a region at the same time is not ready to harvest at same hours but a delay is observed. The study area under investigation was district Sheikhupura, Nankana, Lahore, Gujranawala and Hafizabad, which are famous for rice productivity. Landsat 7, 8 freely available thermal dataset are used to calculated pixel based temperature values to evaluate growth using agricultural growth indicators. The total covered area was $13,480 \mathrm{~km}^{2}$ in which $484 \mathrm{~km}^{2}$ area was marked as less growth rate area with low temperature values due to water body and excess of vegetation over there. About $7960 \mathrm{~km}^{2}$ area is marked as good for growth experiencing optimum temperature for rice plant. Approximately $4944 \mathrm{~km}^{2}$ area is marked as stressed rice plant area experiencing high temperature values adjacent to urban population. An attempt is made here to map this effect of temperature-based growth variability of the rice plant across the study area.
\end{abstract}

\section{Keywords}

Climate, Gross Domestic Product (GDP), Global Warming, Phenology, Temperature 


\section{Introduction}

Pakistan is fortunate to enjoy the rich export quality of Basmati rice that returns three to four times of all the coarse varieties available in international market. The cultivated land area for rice production doubled from 1948 to 1978 due to high demands at national level. The ratio of increment in the area used for rice production increases by roughly $2 \%$ annually. Rice cultivation area increased from 790 thousands ha in 1947 to 2017 thousands ha in 1990 with $163.54 \%$ increment over the period of 44 years with same trend on the way. Production also increased along the same patterns with 693 thousand tons in 1947 and 3220 thousand tons in 1990 giving an increase of $364 \%$. In context of yield, it went on increasing from $877 \mathrm{~kg}$ in 1948 to $1528 \mathrm{~kg}$ in 1990 indicating an increase of 73\% [1].

Punjab Pakistan, is famous for best quality of rice throughout the world. Punjab lies in the temperate and arid zone with extreme variations in weather. It is generally characterized by long hot summer season and cold winters with little rainfall, not more than $255 \mathrm{~mm}$ annually. Summer season is getting longer due to anthropogenic activities which may have a negative impact on rice productivity. This abnormal change in temperature is responsible for dramatic shift in rice productivity regardless of rice crop calendar of Punjab province.

Agricultural productivity is largely influenced by the weather and climate in any region. Productivity is regulated by prevailing climatic factors including light intensity, sunshine duration, rainfall, temperature, air pressure, and humidity level across the region. An increase in atmospheric temperature has considerable effect on growth and quality of rice by affecting its phonology, physiology, and yield components. It is also observed that an increase in temperature by $4^{\circ} \mathrm{C}$ during the growth period of rice plant results in early maturation by five to six days in both wet and dry seasons [2].

Rice plants require a specific amount of heat to develop from seedling to germination and germination to maturation. Crop calendars are used to predict the development stage of rice plant to take management decisions which can often mislead due to unusual climatic variations.

\section{Area under Investigation}

Five districts, including Sheikhupura, Hafizabad, Gujranwala, Nankana Sahib and Lahore are considered, as largest producers of rice comprise of an area known as Eastern Punjab, mapped in Figure 1. Eastern Punjab is the plain area of Pakistan which is connected to India on one side with an average elevation of about $712 \mathrm{ft}$ sea level and adjoining boundary with Sargodha and Faisalabad on the western side. Geospatially it is located between $73 \mathrm{E}$ to $75 \mathrm{E}$ longitude and $31 \mathrm{~N}$ to $32.5 \mathrm{~N}$ latitude with high profile fertile land. Our study area is a subset of Landsat patch with 149 path No and 38 row No.

\subsection{Rice Sequential Stages}

Rice plant undergoes three sequential growth stages that include, vegetative 


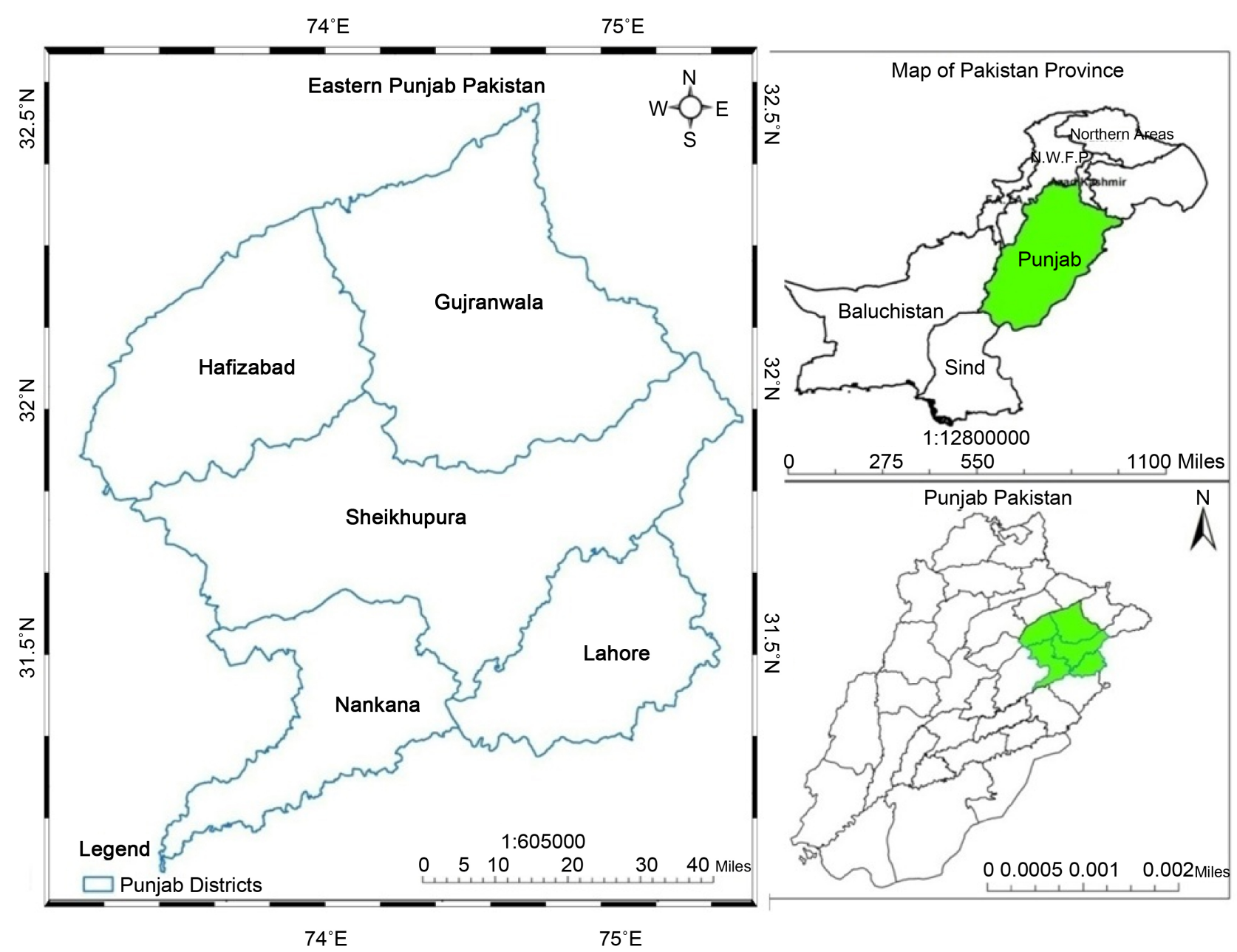

Figure 1. Eastern Punjab Pakistan.

stage, reproductive stage and maturity stage. Vegetative stage takes about 50 to 60 days, reproductive stage takes about 20 to 30 days and the final maturity stage is completed in 30 to 45 days. These stages are further divided in Germination, seed establishment, leaf emergence, tillering, heading, and ripening stage. Duration for each stage is dependent on water availability and environmental conditions in which it is grown.

\subsubsection{Germination Stage}

Germination initializes as white tip appears from surface of land or water, when seed dormancy is broken. A single grain of rice weighs about $12-44 \mathrm{mg}$ depending upon the variety at $0 \%$ moisture content. Hull weighs about $21 \%$ of total grain weight. Germination starts when seed dormancy is broken after absorption of adequate water at temperature ranging between $10^{\circ} \mathrm{C}-40^{\circ} \mathrm{C}[3]$.

Figure 2 describes that water absorption of seed is achieved in less time at higher temperature and vice versa. $60 \%$ moisture content is absorbed by the seed in 54 hours at $30^{\circ} \mathrm{C}$ and the same rate of absorption is obtained in $75-80$ hours at $25^{\circ} \mathrm{C}$ and 110 hours at $20^{\circ} \mathrm{C}$ and so on. 


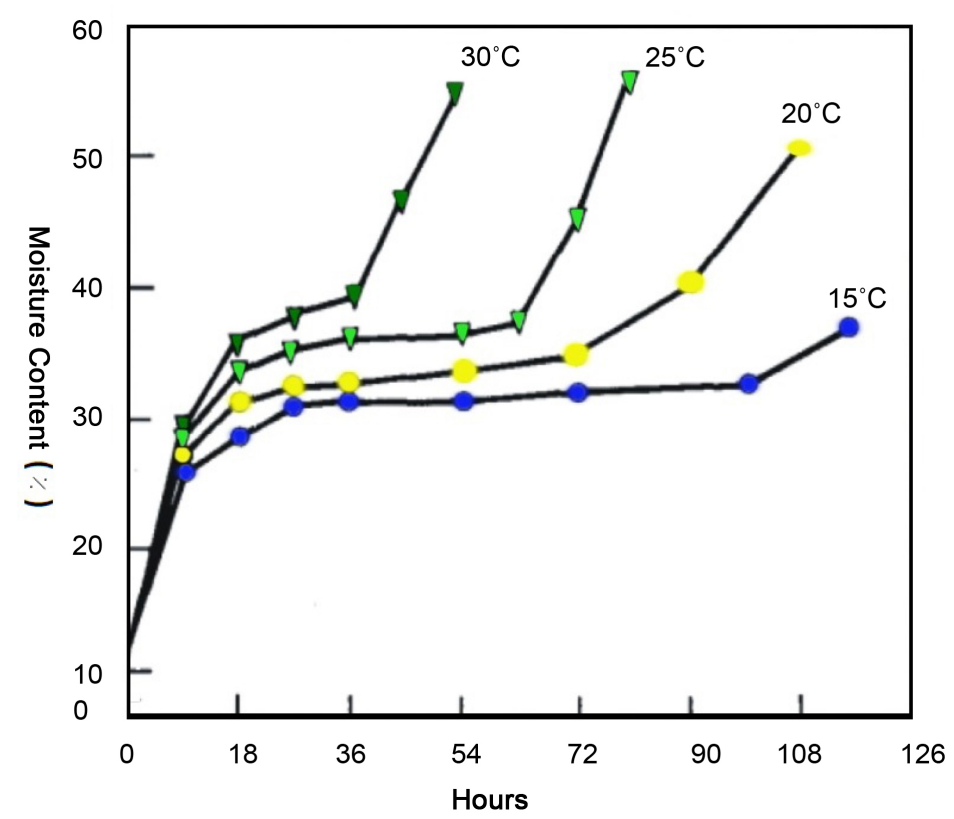

Figure 2. Rate of moisture content absorption at different temperature values.

Temperature has a profound impact on germination. Germination precentage varies at different temperature with a completion period of 2, 3, and 14 days after incubation. $90 \%-97 \%$ germination is achieved in 2 days at a temperature range of $27^{\circ} \mathrm{C}-37^{\circ} \mathrm{C}$, in 3 days at a temperature between $25^{\circ} \mathrm{C}-28^{\circ} \mathrm{C}$, in 6 days between temperature range of $18^{\circ} \mathrm{C}-24^{\circ} \mathrm{C}$ and in 14 days at a temperature range between $14^{\circ} \mathrm{C}-17^{\circ} \mathrm{C}[4]$.

\subsubsection{Seed Establishment Stage}

In the post germination stage the growth is very sensitive to the temperature. Figure 3 describes that maximum cell division occurs at $25^{\circ} \mathrm{C}-30^{\circ} \mathrm{C}$ so this temperature range is considered good for high growth rates. Above and below this range, the seed growth rate becomes slow and the seed may die at $40^{\circ} \mathrm{C}$.

In the second week of germination, rice plant enters into the phase of tissue elongation which results in cell division and cell enlargement. Critical temperature for this growth stage is $30^{\circ} \mathrm{C}$ which slows down while moving toward $15^{\circ} \mathrm{C}$ and it stops below $15^{\circ} \mathrm{C}$ [5].

\section{Material and Methods}

\subsection{Length of Growing Season}

Landsat 8 satellite image of 19-April 2014 is selected for germination of rice plant by verifying the date using [6] midpoint pixel algorithm. Initially time series NDVI data is produced for the area using MODIS 13A2 algorithm which is meaningful for phonological monitoring. White et al., pixel formula is then applied to identify the date of start of season for rice plantation. This algorithm is sophisticated and widely used to identify the time span of length of growing 


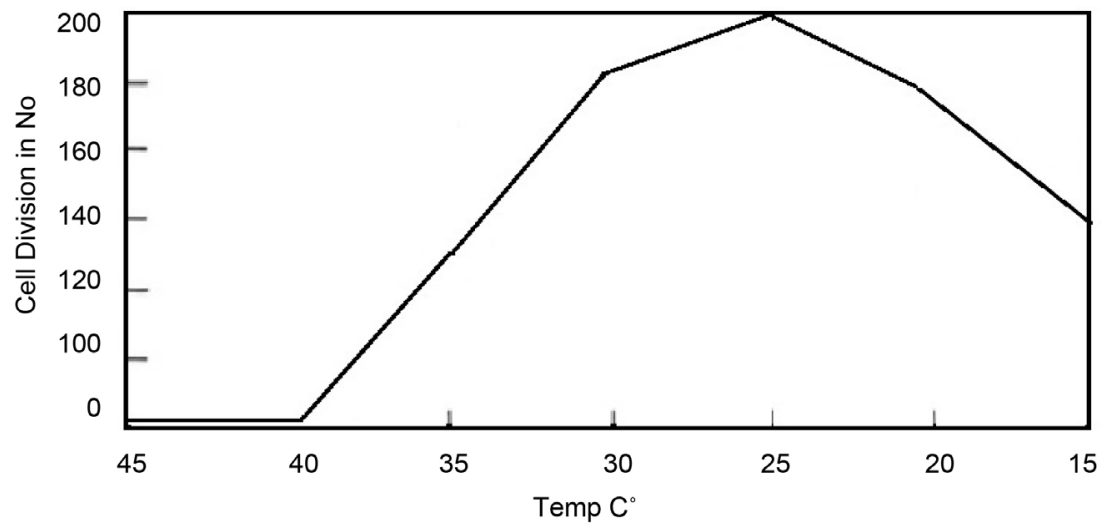

Figure 3. Rate cell division at different temperature values.

season. This algorithm is formulated as following.

$$
\mathrm{NDVI}_{\text {Ratio }}=\frac{\mathrm{NDVI}-\mathrm{NDVI}_{\min }}{\mathrm{NDVI}_{\text {max }}-\mathrm{NDVI}_{\min }}
$$

In Equation (1) NDVI is interpolated daily NDVI value throughout the year 2014. $\mathrm{NDVI}_{\max }$ and $\mathrm{NDVI}_{\min }$ are the maximum and minimum values recorded in a year. Start of season is defined as the day of year when $\mathrm{NDVI}_{\text {Ratio }}$ exceeds 0.5 as this is considered to correspond to the timing of most rapid increase in NDVI to the initial leafing of our stormy canopy.

\subsection{Procedure of Temperature Calculation Using Landsat 8 Thermal Bands}

Landsat 8 datasets used in this research are freely available on earth explorer website. These datasets consist of two thermal bands, B10 and B11 with $100 \mathrm{~m}$ spatial resolution in atmospheric window between $10 \mu \mathrm{m}$ and $12 \mu \mathrm{m}$. These datasets are used here to calculate temperature against each pixel on the ground.

\subsection{Calculation of Irradiance}

Initially the DN values are converted into radiance. Radiance gives the flux of radiant energy per unit area.

Radiance is calculated here using the following formula.

$$
\text { Irradiance }=\left(3.342 \times 10^{-4} \times \text { Thermal Band }\right)+0.1 \quad[7]
$$

The value of 3.3420E-04 in Equation (2) is extracted from metadata of Landsat 8 Image. This formula helps to calculate Irradiance against each pixel across the image in Watts $/\left(\mathrm{m}^{2} \cdot \operatorname{srad} \cdot \mu \mathrm{m}\right)$. Figure 4 determines the irradiance based variations in the study site, where Lahore shows the highest irradiance values due to highest soil fulx.

\section{Results and Discussion}

\subsection{Temperature Calculation}

For temperature calculation, the dataset of irradiance calculated earlier is used 


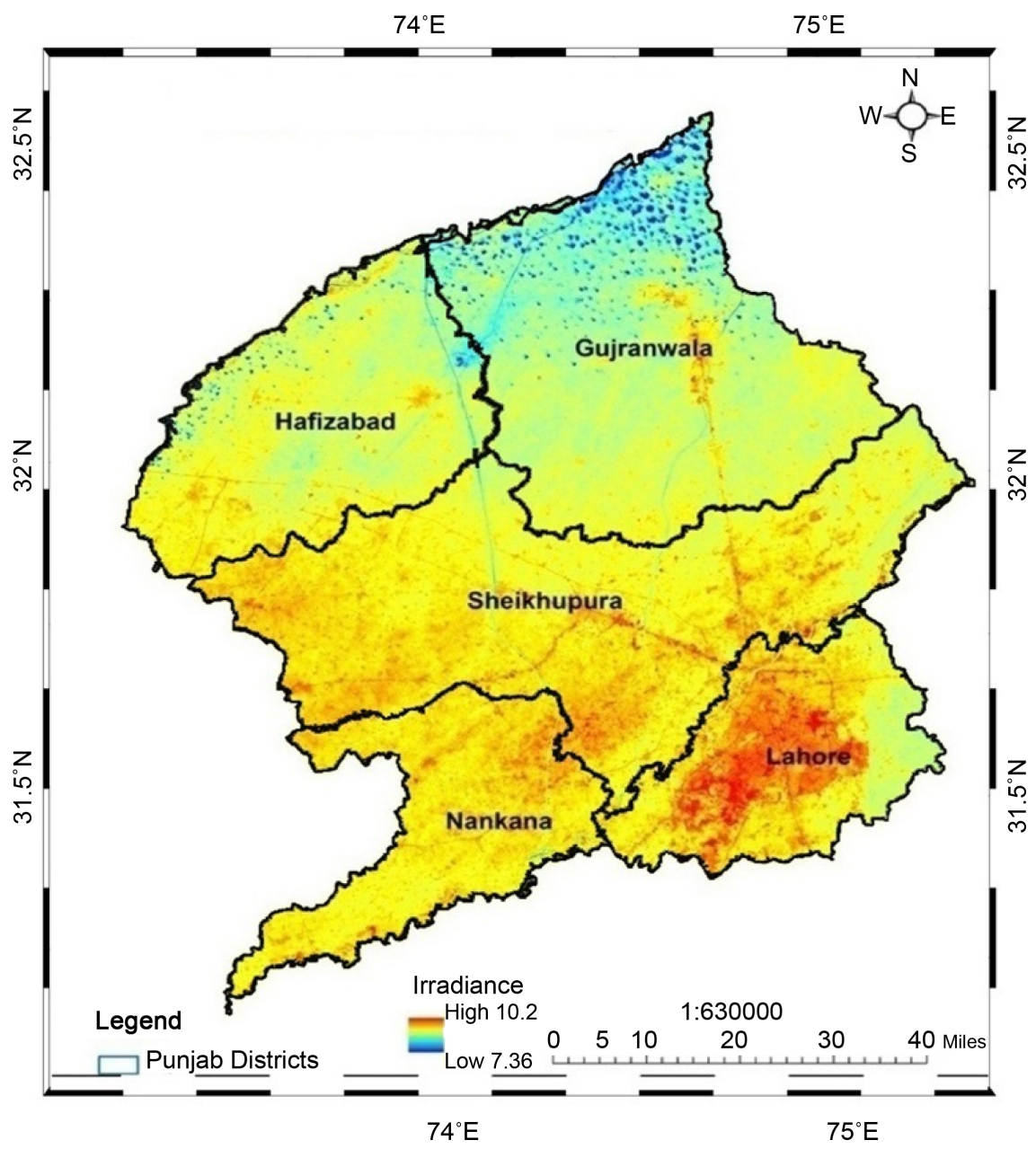

Figure 4. Irradiance map of study area.

and the following algorithm applied

$$
T=\left\{K_{2} / \ln \left(\varepsilon K_{1} / \text { Irradiance }+1\right)\right\}-272.15
$$

In Equation (3), $K_{1}$ and $K_{2}$ are the constants for thermal bands and their values are mentioned in metadata Landsat, in our case we used following values of these constants.

$$
\begin{aligned}
& \text { K1_CONSTANT_BAND_10 }=774.89 \\
& \text { K1_CONSTANT_BAND_11 }=480.89 \\
& \text { K2_CONSTANT_BAND_10 }=1321.08 \\
& \text { K2_CONSTANT_BAND_11 }=1201.14
\end{aligned}
$$

$\varepsilon$ is emissivity which is taken as 0.95 generally. However many authors have calculated this factor by using indices such as Normalized Difference Vegetation Index etc. to examine soil emissivity level. The spatial distribution of the temperature values in the study site are mapped in Figure 5.

\subsection{Histogram Evaluation}

The histogram in Figure 6 is generated using temperature based dataset calculated 


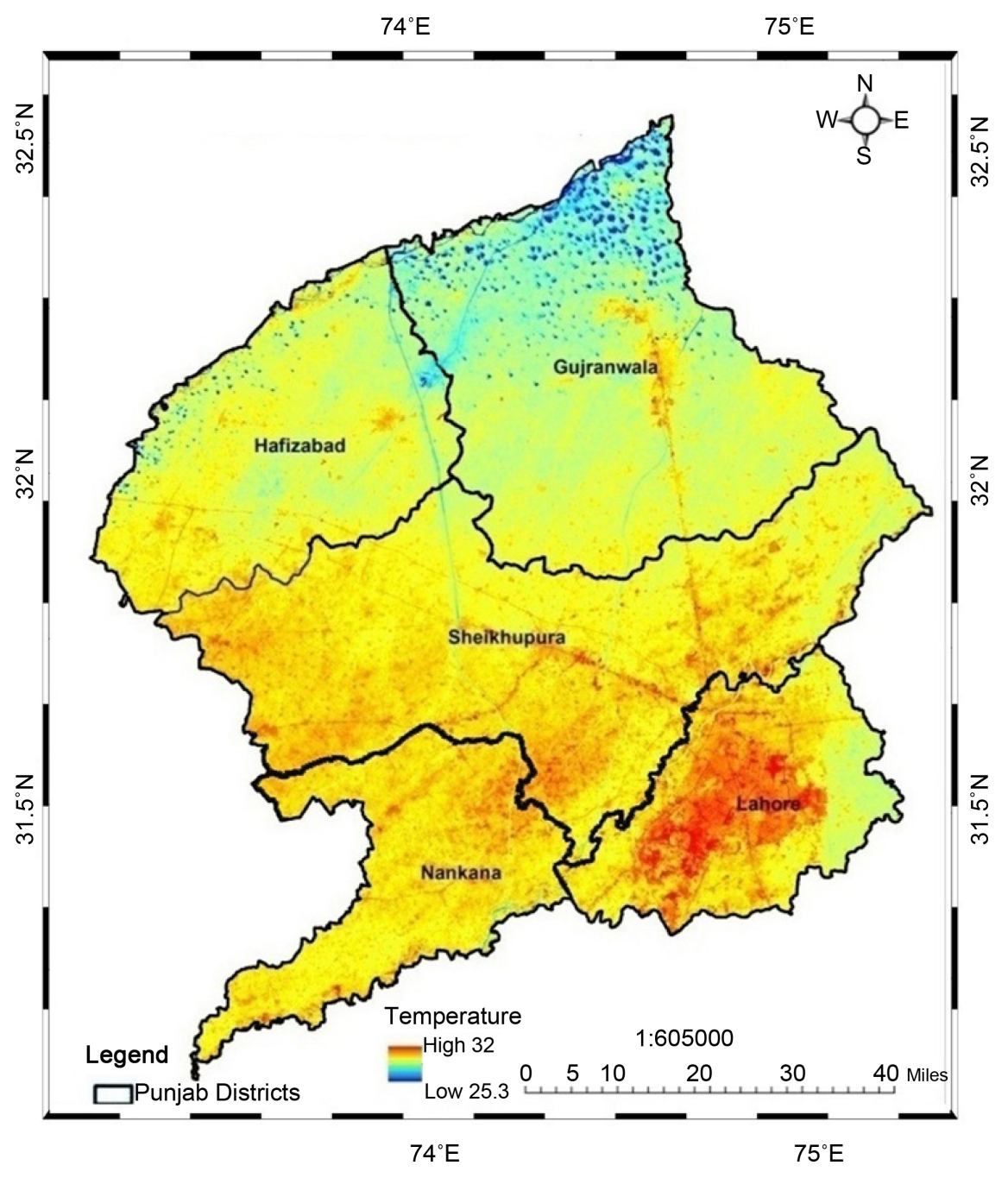

Figure 5. Temperature map of study area.

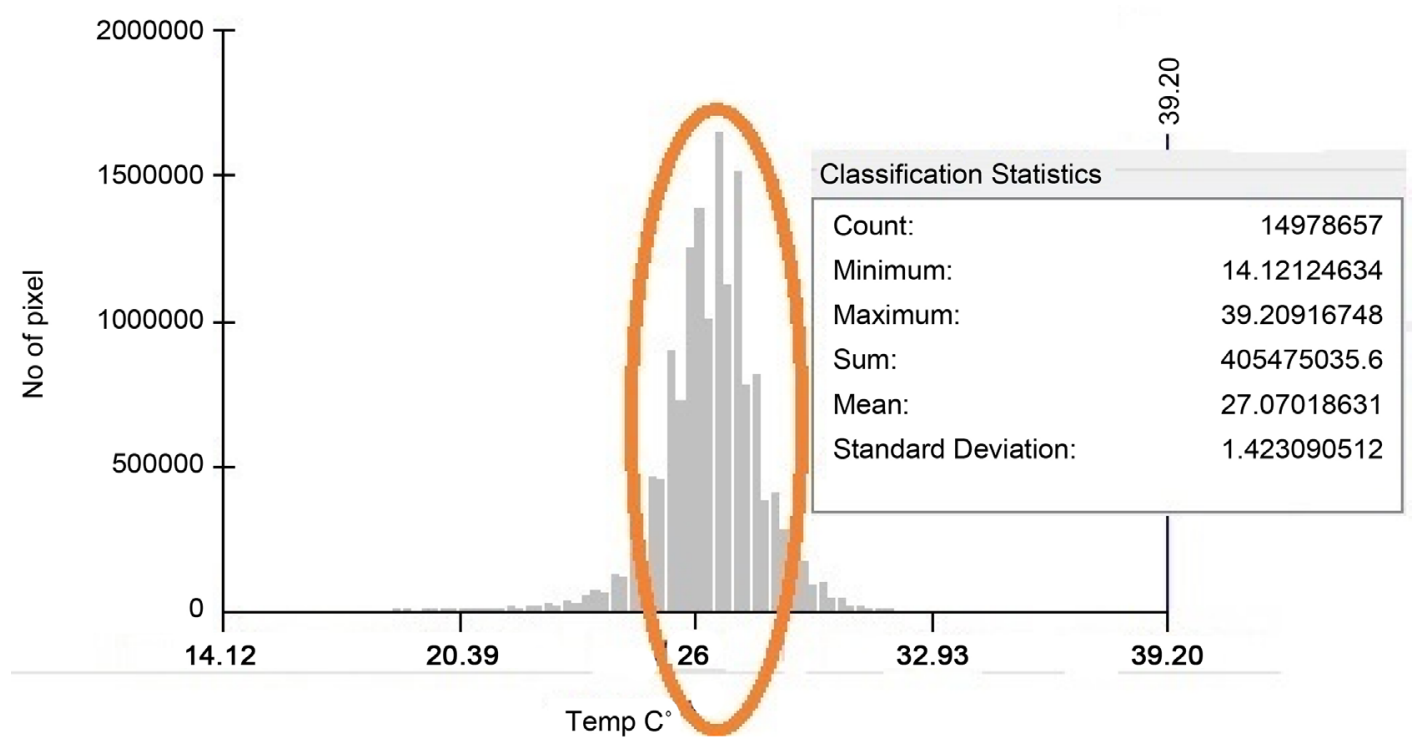

Figure 6. Histogram of temperature and pixel density. 


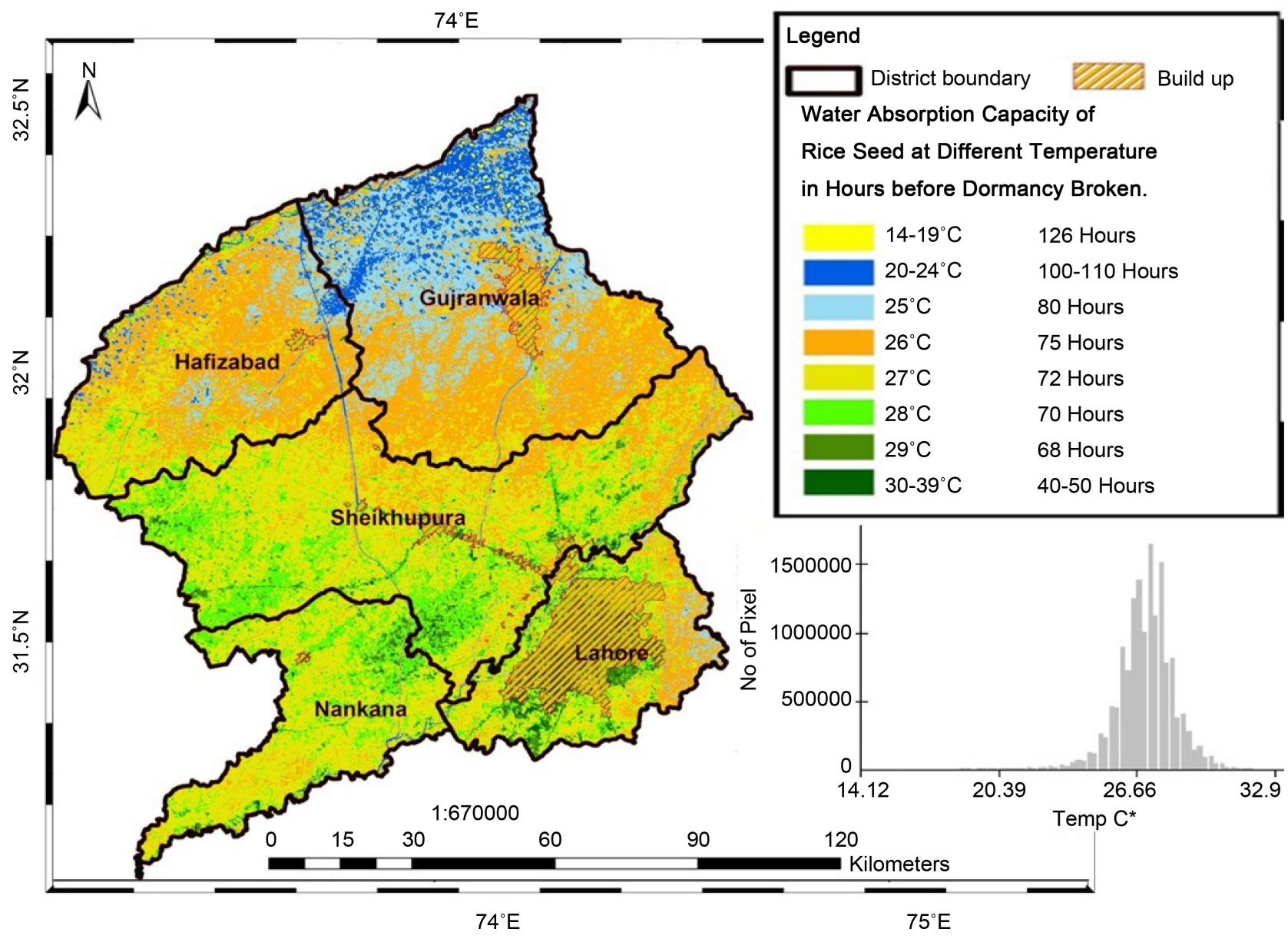

Figure 7. Water absorption capacity map of Study area using Landsat 8 image of date 19-04-2014. 


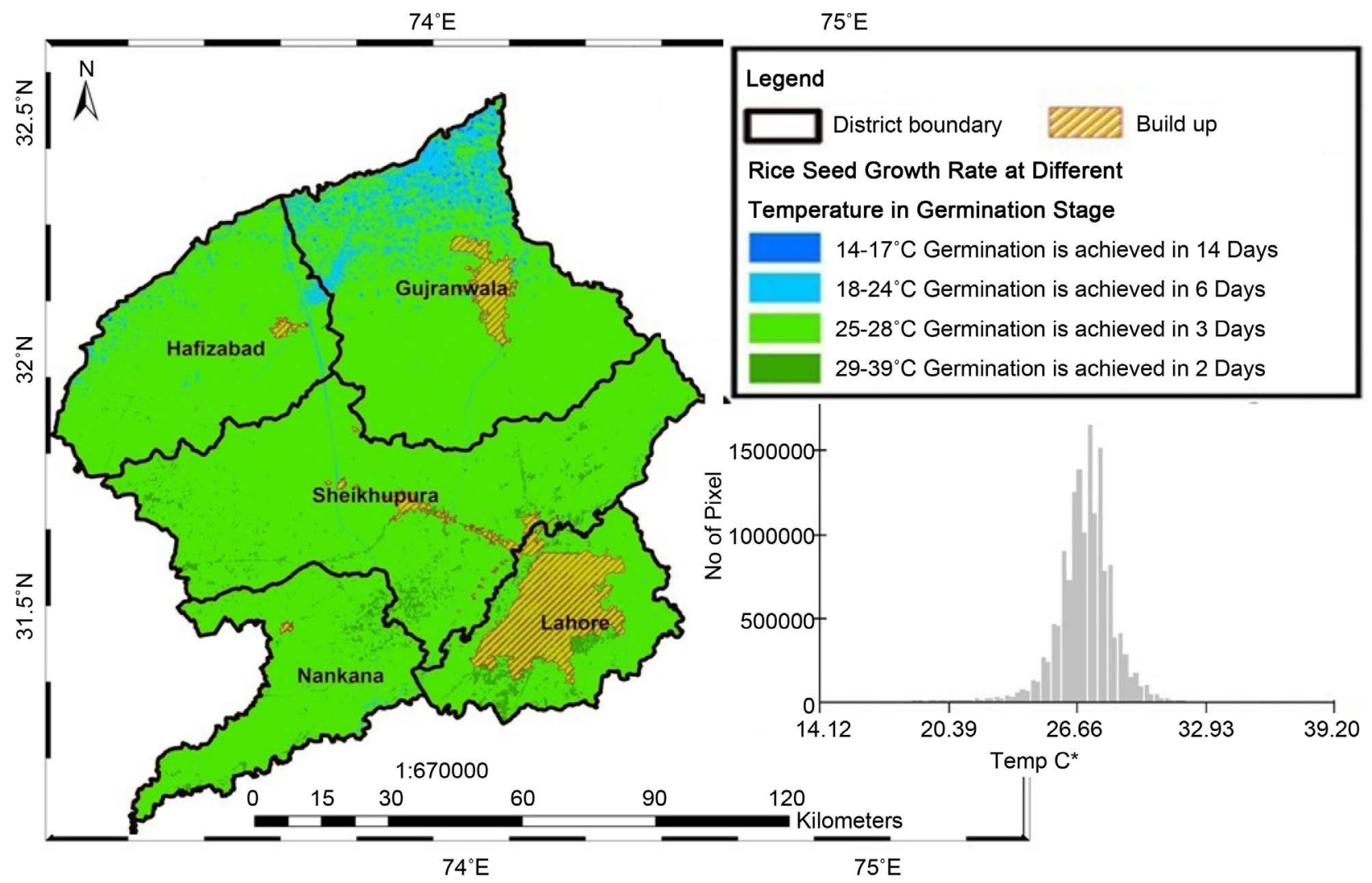

Figure 8. Germination map of study area using Landast8 satellite image of 05-May-2014.

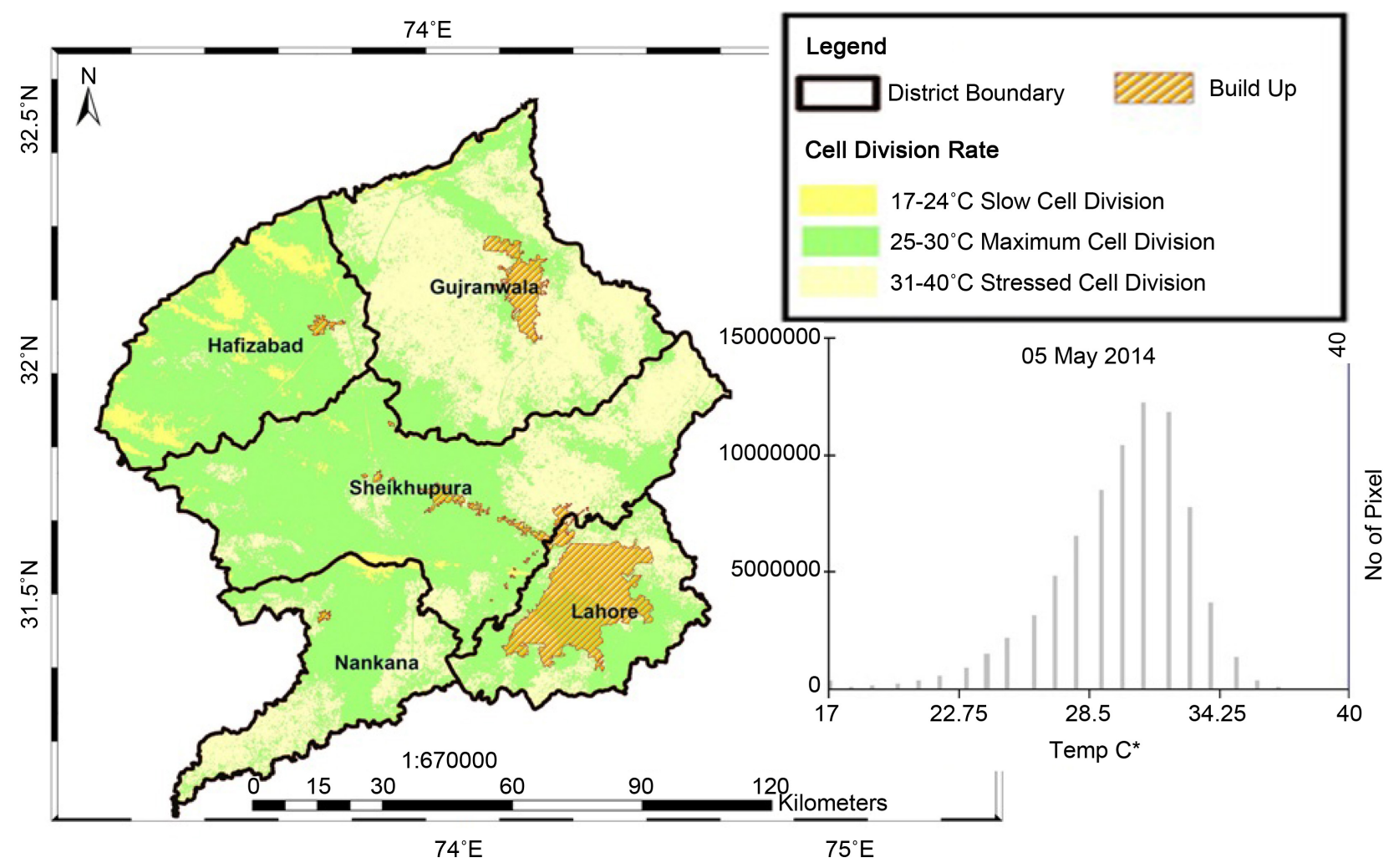

Figure 9. Rice seed cell division map of study area using Landsat 8 image of date 05-May-2014. 


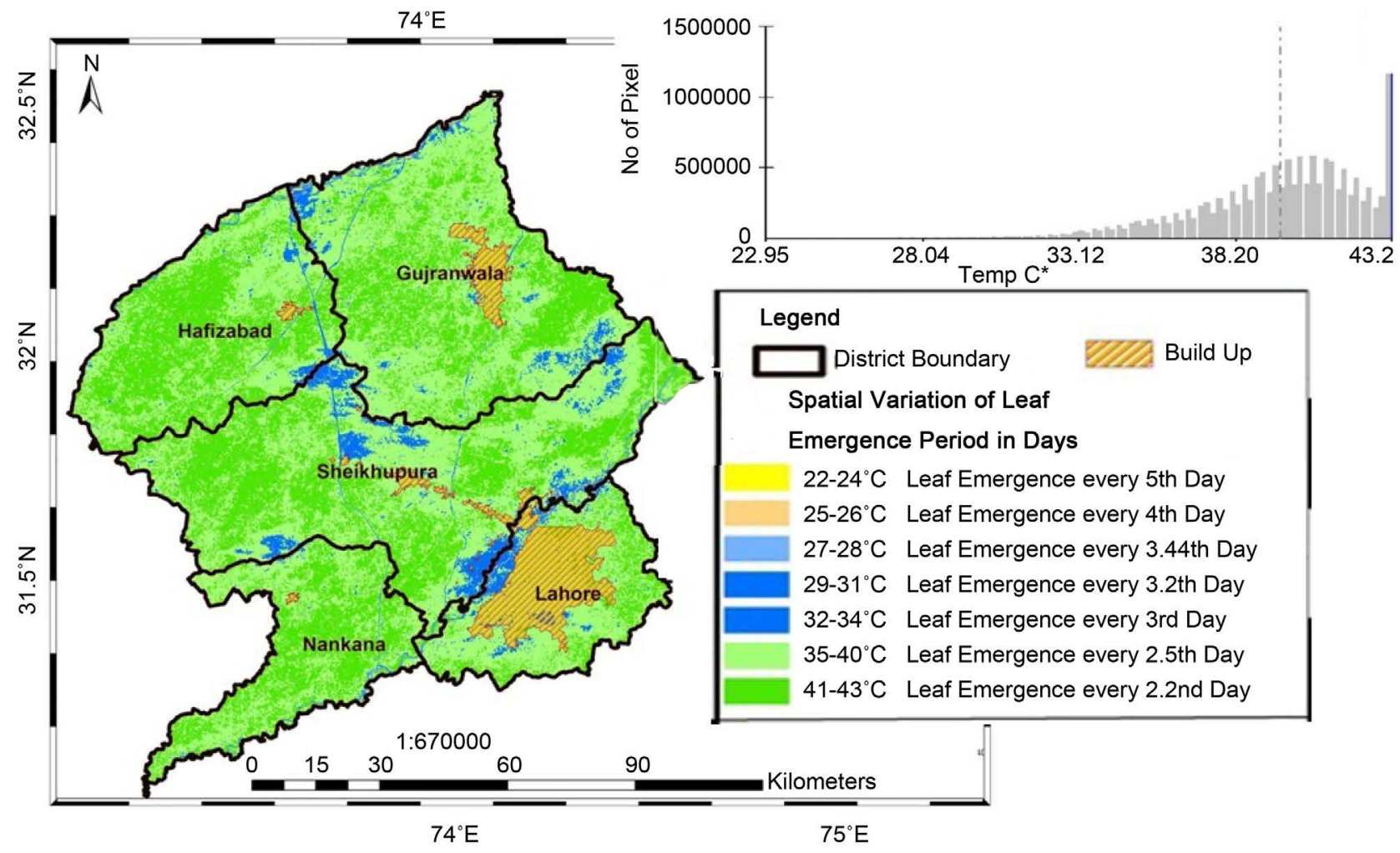

Figure 10. Leaf emergence map of rice plant in the study area using Landsat Image of date 21-May-2014.

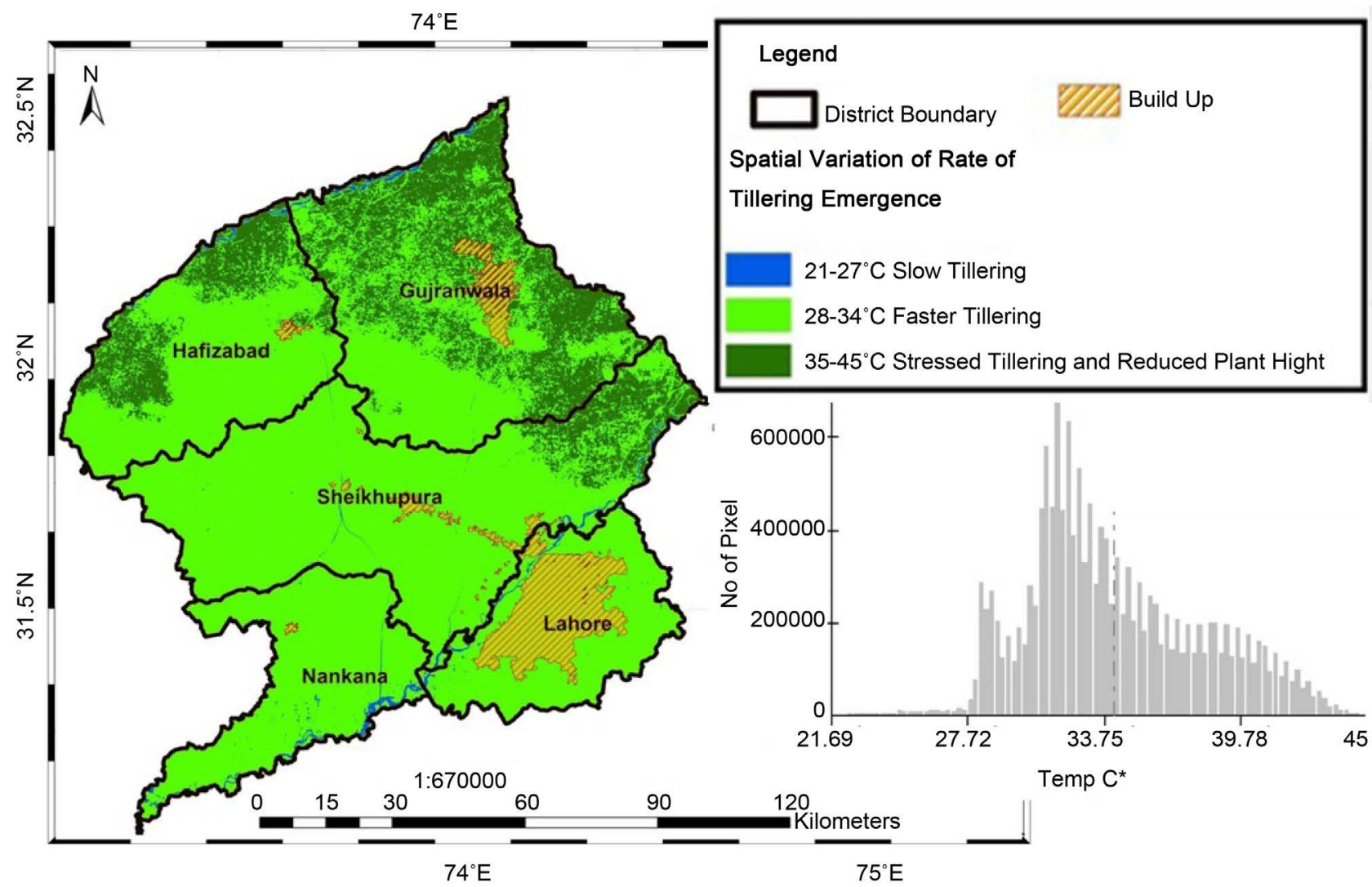

Figure 11. Tillering map of rice plant in the study area using Landsat Image of the date 22-June-2014. 


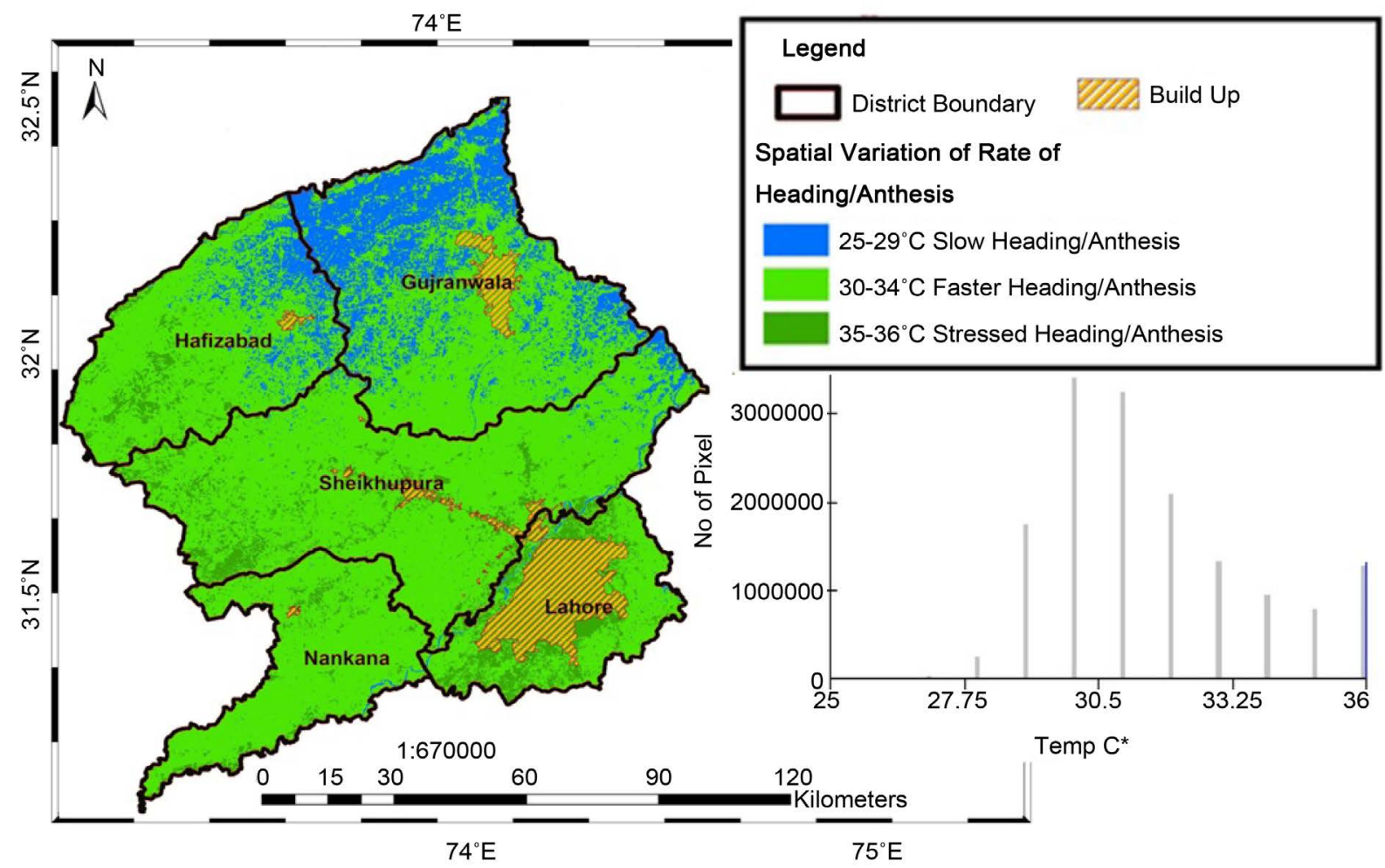

Figure 12. Heading/Anthesis map of rice plant in the study area using Landsat Image of the date 25-August-2014.

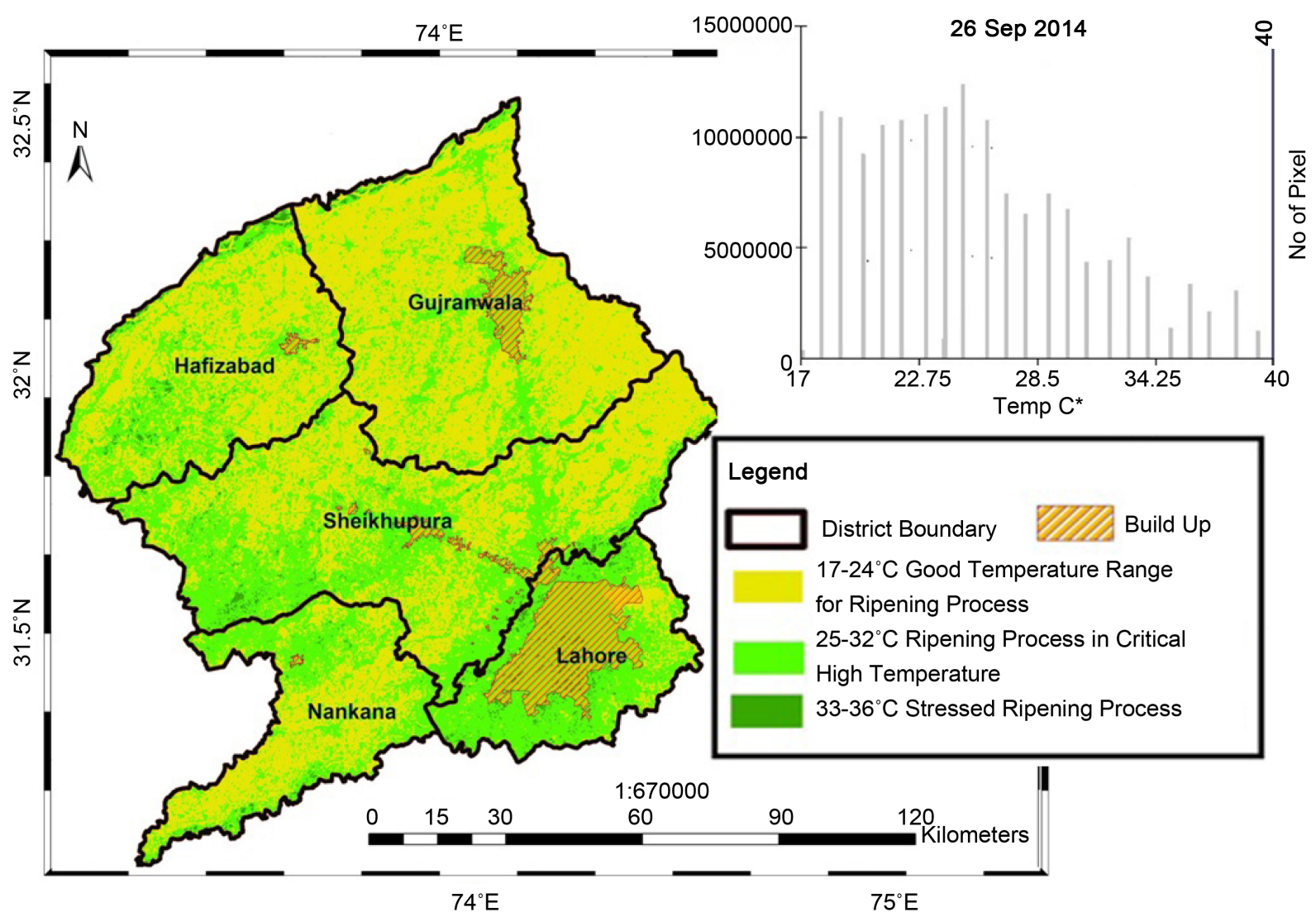

Figure 13. Repining map of rice crop in the study area using Landsat image of the date 26-Sep-2014. 
city with higher temperature values that produce short heighted, stressed plants with less yield. The stressed plants are the result of low metabolism with considerable damage to the plant, sometimes leading to cell death. High concentration of environmental pollution in metropolitan areas, cause an artificial green house impact on rice crop which results in an increase of temperature and finally the stressed vegetation.

Rice crop cultivated near to water body is exposed to comparatively low temperatures that are less than optimum range which results in slow growth for each stage of rice plant development and a sharp decrement in rice plant development is observed. Finally the crop is delayed and results a lengthy growing season in the regions adjacent to water body.

\subsection{Leaf Emergence}

A rice leaf is composed of a sheet, ligules, blade and auricle. The sheet ribbon shaped structure is rolled into a cylinder that includes all the parts of a shoot. The blade is a longer, flat but narrow part of a leaf. Temperature has profound impact on leaf emergence stage. High temperature speeds up leaf emergence process. Leaf emerges every fifth day for the rice plant facing $20^{\circ} \mathrm{C} .100$ degree days are recommended for first leaf emergence so 5 days are required $(100 / 20=$ 5 days) at $20^{\circ} \mathrm{C}$ and every fourth day at $25^{\circ} \mathrm{C}$ which is $(100 / 25=4$ days $)$. Succeeding leaf emergence happen after the former leaf has completed its emergence. Upper leaves have longer life span than the lower ones.

\subsection{Tillering Stage}

Tiller are the branches that emerge from the axil during vegetative stage. The first leaf of tiller emerges from second leaf of main Culm when the fifth leaf on the main Culm emerges. Similarly the second leaf of tiller develops. This process of tiller emergence continues till the emergence of last leaf. This rule is not only applicable on the main Culm but to all tillers

\subsection{Heading Stage}

The time of initiation of Panicle from the boot is known as heading. This process takes about 10 - 14 days for 100 percent development depending upon environmental conditions in which it is exposed. Temperature conditions play a vital role in this stage, for example, a sharp increase in number of days is observed as temperature drops from $24^{\circ} \mathrm{C}$ to $21^{\circ} \mathrm{C}$. A temperature drop of $1^{\circ} \mathrm{C}$ causes a delay of 13 days in heading. When temperature is increased, number of days are decreased from 91 at $27^{\circ} \mathrm{C}$ to 86 days at $30^{\circ} \mathrm{C}$. Flowering starts as the process of heading ends that continues for up to 7 days. The floral organ of rice including Lemma and Palea is called spikelet. Anthesis is a series of event of opening and closing spikelet which lasts within $1-2.5$ hours

\subsection{Ripening Period}

Ripening period is defined by increase in size and weight and change in color of 
grain from green to yellow periodically. In the early stage, the grains of rice are green that turn to yellow and the texture of grain turns from milky to dough and yellow ripe to maturity. Considerable amount of sugar and starch in the plant leaf sheet and Culm is translocated to the grain during ripening period. Duration of grain filling up to maturity differs with different rice varieties. For example Indica rice variety IR20 takes 13 days at mean temperate of $28^{\circ} \mathrm{C}$ and 33 days at $16^{\circ} \mathrm{C}$ to reach ripening period. A japonica rice variety Fujiska 5 takes 18 days at a mean temperature of $28^{\circ} \mathrm{C}$ and 43 days at $16^{\circ} \mathrm{C}$ because water content decreases faster at high temperatures, however above a certain limit temperatures can cause stress in growth which results in low yield. $15^{\circ} \mathrm{C}-21^{\circ} \mathrm{C}$ is considered optimum temperature in repining stage while $22^{\circ} \mathrm{C}-29^{\circ} \mathrm{C}$ is critical high. High temperature during grain filling results in increased respiration and more carbohydrates consumption. This result in less filled spikelet and reduced yield, therefore night time is considered good during the grain filling stage.

The objective of this paper is to incorporate the Landsat 8 , Thermal band data to calculate temperature values against each pixel in the study area. Spatial variation of these heat units will help to mark the regions with slow or fast growth rates of rice plant in various growth stages e.g. (Germination, Tillering, Anthesis and ripening etc.) described briefly above.

\section{Conclusions}

Remote sensing and GIS techniques applied in this research, not only proved to be very useful in spatio-temporal monitoring of rice plant at various growth stages, but also remained time efficient for a large study area. Remote Sensing and GIS techniques are capable of extraction of error free data to develop temperature based thematic maps instead of manual techniques of data collection of wide areas which are always time consuming and more expansive.

Rice plantation near to cities and closer to the road network experienced high temperature which resulted in stressed and short heighted plants due to high concentration of environmental pollution including $\mathrm{SO}_{\mathrm{x}}, \mathrm{NO}_{\mathrm{x}}$ and particulate matter. Rice plantation near to water body e.g. Rivers, Canals and Nalas, experienced comparatively low temperature values which resulted in slow growth rate. All the histograms developed in this study show that highest density of temperature values are falling in optimum temperature for particular growth stage so our study area is good for rice plantation. Rice plantation in our study are sown at same time is not ready to harvest at the same time but there is a delay due to heat units experienced by a single rice plant. We could not get thermal bands with 1day temporal resolution. However, if such high temporal resolution data are obtained, best results regarding growth monitoring against each growth stage may be achieved and finally a best yield.

\section{Acknowledgements}

The authors are thankful to the United States Geological Survey (USGS) for pro- 
vision of a value able data that we used in this research. We are also thankful to worthy Vice Chancellor of the University of the Punjab Pakistan for provding us a good environment to complete this research.

\section{References}

[1] Qureshi, K.A., et al. (1993) Contribution of Area and Yield of Total Rice Production in Pakistan-An Analysis. Pakistan Journal of Agriculture Science, 30.

[2] Ziska, E., Fraser, D., et al. (1997) Assessing Risks of Climate Variability and Climate Change for Rice. Science, 240, 996-1002.

[3] Livingston, B.E. and Haasis, F.W. (1932) Relations of Time and Maintained Temperature to Germination Percentage for a Lot of Rice Seed. American Journal of Botany, 596-615.

[4] Yoshida, S. (2012) Effects of Temperature on Growth of the Rice Plant (Oryza sativa L.) in a Controlled Environment. Soil Science and Plant Nutrition, 302-304.

[5] Nakagava (2003) Response of Rice to Increasing Temperature and Atmospheric CO2. Environmental Sciences and Engineering, 63-80.

[6] White, M.A., de Beurs, K., Didan, K., Inouye, D., Richardson, A., Jensen, O., et al. (2009) Inter Comparison, Interpretation, Assessment of Spring Phonology in North America Estimated from Remote Sensing for 1982-2006. Global change Biology, 15, 2335-2359.

[7] http://landsat.usgs.gov/Landsat8_Using_Product.php 